\title{
PENGURANGAN CEMARAN LOGAM BERAT PADA PERAIRAN DAN PRODUK PERIKANAN DENGAN METODE ADSORBSI
}

\author{
Tuti Hartati Siregar")
}

\begin{abstract}
ABSTRAK
Kandungan logam berat yang terdapat dalam jumlah yang kecil di perairan dibutuhkan oleh makhluk hidup, tetapi dalam jumlah besar dapat menyebabkan berbagai masalah. Kehadiran industri berperan dalam meningkatkan cemaran logam berat. Berbagai cara telah dilakukan untuk mengurangi cemaran logam berat. Metode adsorbsi adalah cara yang banyak digunakan untuk mengurangi cemaran logam berat, karena aplikasinya yang cukup luas untuk berbagai jenis logam berat. Beberapa bahan alami yang ramah lingkungan seperti kitosan dan selulosa dapat digunakan sebagai adsorben. Baik kitosan maupun selulosa harus melewati tahap modifikasi untuk meningkatkan efektifitasnya sebelum digunakan sebagai adsorben.
\end{abstract}

\section{ABSTRACT: The reduction of heavy metal pollution in waters and fisheries products by means of adsorption method. By: Tuti Hartati Siregar}

The presence of heavy metal in a minute amount in waters are needed by living organisms. On the other hand, their present in a large amount may cause a serious problem. Industrial process in particular is responsible for the pollution of heavy metal. There are many methods that have been employed to solve this problem. However, the adsorption method is the most common technique to reduce the contents of heavy metal due to its wide application for various kind of heavy metal. There are several natural products that are also environmentally friendly such as chitosan and cellulose that could be employed as adsorben. Both agents, however, have to be modified prior their application to enhance their effectivity.

\section{KEYWORDS: $\quad$ adsorption, heavy metal, adsorben's modification, chitosan, cellulose}

\section{PENDAHULUAN}

Kandungan logam berat pada berbagai produk pangan menjadi masalah yang cukup serius, karena logam berat tidak dapat dimetabolisme dan akan terakumulasi dalam tubuh sehingga berpotensi menjadi racun yang dapat membahayakan kesehatan manusia. Logam berat dapat didefinisikan sebagai logam yang mempunyai densitas atom lebih besar dari $6 \mathrm{~g} / \mathrm{cm}^{3}$ (O'Connel et al., 2008). Menurut definisi ini yang termasuk logam berat diantaranya adalah Merkuri ( $\mathrm{Hg}$ ), Arsen (As), Kadmium (Cd), Kromium (Cr), Tembaga (Cu), dan Timbal (Pb).

Logam berat dalam jumlah kecil bermanfaat bagi mahluk hidup sebagai mikronutrisi, tetapi dalam jumlah yang besar kehadiran logam berat akan menimbulkan masalah. Keracunan timbal akan menyebabkan kerusakan ginjal, anemia, gangguan sistem reproduksi, dan ketidakseimbangan syaraf kognitif (Pagliuca \& Mufti, 1990). Kromium bersifat toksik, dalam bentuk senyawa heksavalen dapat mengakibatkan kanker paru-paru (IARC, 1990). Konsumsi tembaga yang berlebih dapat mengakibatkan penurunan daya tahan tubuh, anoreksia, dan rasa malas (Theopanides \&
Anastassopoulou, 2002). Merkuri sangat berbahaya dalam bentuk senyawa metil merkuri. Keracunan senyawa metil merkuri dapat menyebabkan kebutaan, kerusakan syaraf, keterbelakangan mental, penurunan tingkat kecerdasan, disleksia, penurunan konsentrasi, dan hiperaktif (Mulyono, 2000; Weiss \& Landrigan, 2000).

Untuk menghasilkan produk yang berdaya saing, selain masalah kualitas produk, masalah keamanan pangan juga harus menjadi perhatian utama. Cemaran logam berat dalam produk pangan harus dihilangkan atau dikurangi kadarnya agar produk tersebut aman untuk dikonsumsi. Badan Pengawas Obat dan Makanan (BPOM RI) mensyaratkan ambang batas bagi logam berat dalam perairan untuk budidaya perikanan adalah $\mathrm{Hg} 0,002 \mathrm{mg} / \mathrm{L}$, As $1 \mathrm{mg} / \mathrm{L}, \mathrm{Cd}$ 0,01 $\mathrm{mg} / \mathrm{L}, \mathrm{Pb} 0,03 \mathrm{mg} / \mathrm{L}$, dan Cu 0,02 mg/L (Anon., 1990). Berbagai metode telah dilakukan oleh para ahli untuk mengurangi cemaran logam berat, tetapi metodemetode yang digunakan tersebut umumnya baru bisa diterapkan pada lingkungan perairan bukan pada produk perikanan. Beberapa metode yang digunakan dalam menghilangkan cemaran logam berat terlarut diantaranya adalah dengan cara pengendapan, penukar ion, filtrasi membran, reduksi elektrolitik, dan adsorbsi (Kurniawan et al., 2006; Wang et al., 2003).

\footnotetext{
*) Peneliti pada Balai Besar Riset Pengolahan Produk dan Bioteknologi Kelautan dan Perikanan
} 


\section{PENGURANGAN LOGAM BERAT}

\section{Beberapa Metode Pengurangan Cemaran Logam Berat}

Cemaran logam berat dapat dikurangi dengan berbagai metode, antara lain :

\section{Metode pengendapan}

Metode ini secara kimia merupakan metode yang paling sederhana dari seluruh metode yang ada dalam mengurangi cemaran logam berat. Metode ini bisa dipakai pada hampir seluruh logam berat dan biaya yang diperlukan tidak mahal (Wang et al., 2004 dalam O'Connel et al., 2008). Metode ini mempunyai beberapa kekurangan diantaranya lumpur yang mengandung logam berat sebagai limbah hasil reaksi sangat banyak, sehingga dibutuhkan biaya untuk membuat tempat penampungan buangan tersebut serta perawatannya cukup mahal (Aderhold et al., 1996). Metode pengendapan secara kimia umumnya digunakan untuk mengurangi cemaran logam pada perairan, karena sampel yang cocok untuk metode ini adalah sampel yang berbentuk cairan.

\section{Metode penukar ion}

Metode ini penggunaannya selektif hanya untuk logam-logam tertentu, toleransi $\mathrm{pH}$ terbatas, dan perkembangannya cukup pesat. Penggunaan metode penukar ion memerlukan biaya yang cukup besar sebagai modal awal dan perawatan alat (Aderhold et al., 1996). Metode penukar ion ini juga lebih banyak digunakan untuk perairan. Sampel harus dibuat dalam bentuk cairan agar dapat dilewatkan pada kolom yang mengandung resin penukar ion.

\section{Metode filtrasi membran}

Metode ini mempunyai kelebihan diantaranya menggunakan sedikit bahan kimia, limbah padat yang dihasilkan sedikit, tempat yang dibutuhkan kecil, dan memungkinkan untuk digunakan secara selektif terhadap logam-logam tertentu. Kelemahannya adalah biaya yang dibutuhkan untuk modal awal, perawatan alat, dan operasi alat cukup besar. Kotoran yang mengendap pada membran juga akan mengakibatkan laju alir menjadi lambat (Madaeni \& Mansourpanah, 2003; Qin et al., 2002). Seperti halnya metode penukar ion, metode filtrasi membran lebih cocok digunakan untuk sampel yang berbentuk cair.

\section{Metode reduksi elektrokimia}

Metode ini tidak membutuhkan bahan kimia dalam pengoperasiannya, juga dapat digunakan untuk padatan tersuspensi. Kelemahannya adalah biaya untuk memproduksi $\mathrm{H}_{2}$ cukup besar, juga membutuhkan proses filtrasi (Kongsricharoern \& Polprasert, 1996). Metode reduksi elektrokimia selain dapat digunakan untuk perairan yang tercemar logam berat juga dapat digunakan untuk produk/ biota tetapi produk/biota tersebut harus dibuat dalam bentuk padatan tersuspensi.

\section{Metode pengurangan logam berat dengan cara} adsorbsi

Metode ini sangat tergantung pada adsorben yang digunakan. Keuntungan penggunaan metode ini adalah dapat dipakai untuk berbagai macam target polutan, kapasitas besar, reaksi kinetik cepat, dan cukup selektif tergantung pada pemilihan adsorben. Kelemahannya adalah sangat tergantung pada pemilihan adsorben serta membutuhkan modifikasi adsorben secara kimiawi untuk meningkatkan kemampuan adsorbsi (Crini, 2005). Penggunaan metode adsorbsi sangat luas, dapat digunakan untuk sampel air dan sampel padat. Metode adsorbsi cocok digunakan untuk mengurangi cemaran logam berat dalam produk perikanan tanpa harus mengubah produk tersebut menjadi bentuk cairan terlebih dahulu.

Metode yang paling banyak digunakan untuk menghilangkan cemaran logam adalah dengan menaikkan $\mathrm{pH}$ lalu mengubah logam berat dari bentuk terlarut menjadi bentuk tidak larut. Reaksi penukar ion adalah metode kedua yang paling luas penggunaannya (Shukla et al., 2002). Metode adsorbsi merupakan metode yang cukup efektif dalam mengurangi cemaran logam berat dari air limbah. Metode adsorbsi bisa bersifat reversibel sehingga pengoperasiannya lebih ekonomis (Kelleher, 2001 dalam O'Connell et al., 2008).

\section{Aplikasi Kitosan dan Selulosa sebagai Adsorben Logam Berat}

Keberhasilan penggunaan metode adsorbsi dalam mengurangi cemaran logam berat sangat tergantung pada pemilihan adsorben. Selain itu adsorben yang digunakan juga harus dimodifikasi terlebih dahulu agar selektif mengikat logam berat target. Beberapa bahan yang telah digunakan untuk mengadsorbsi logam berat di antaranya kitosan, selulosa (batang pisang, sabut kelapa, serbuk gergaji), tanah liat, dan arang. Metode adsorbsi cocok digunakan baik untuk sampel yang berbentuk cair maupun padat. Pengurangan cemaran logam berat pada produk perikanan lebih cocok menggunakan kitosan dan selulosa karena kedua bahan tersebut tidak memberikan efek negatif pada kesehatan manusia. Tanah liat dan arang lebih cocok digunakan untuk mengurangi logam berat dari perairan karena kedua bahan tersebut bukan bahan yang cocok digunakan untuk produk pangan. Modifikasi tanah liat dan arang sebagai adsorben juga membutuhkan 


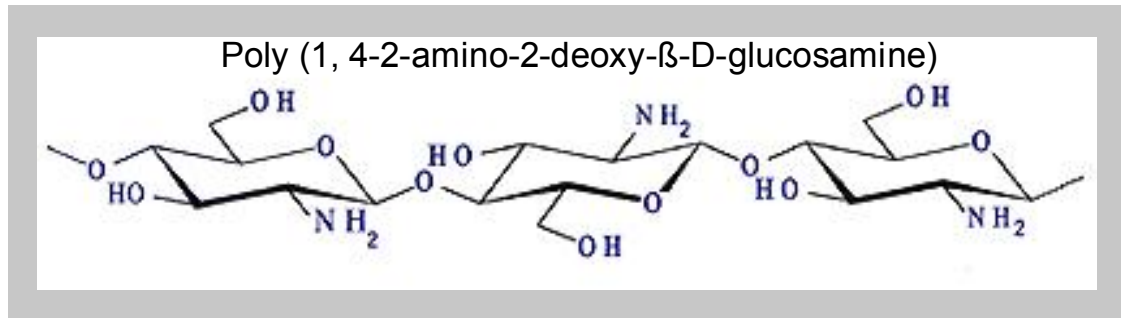

Gambar 1. Struktur kitosan (Anon., 2009a).

biaya yang besar, tidak sebanding dengan daya adsorbsinya yang lemah (Say et al., 2008).

\section{Kitosan}

Kitosan merupakan produk deasetilasi dari kitin yang bahan bakunya berasal dari cangkang invertebrata seperti udang dan serangga. Kitosan dapat digunakan sebagai adsorben yang ramah lingkungan karena bersifat dapat terurai di alam. Di samping itu kelimpahannya cukup banyak di alam. Struktur kimia kitosan mirip dengan selulosa (Baba et al., 1998). Kemampuan kitosan mengadsorbsi logam berat disebabkan oleh gugus amino yang terdapat dalam kitosan.

\section{Modifikasi kitosan}

Beberapa ahli telah melakukan modifikasi kitosan untuk meningkatkan daya adsorbsinya, di antaranya dengan mensintesis senyawa silika-kitosan melalui ikatan kovalen (Cestari et al., 2005; Li et al., 2007). Copello et al. (2006) kemudian melakukan perbaikan dengan membuat komposit silikat-kitosan. Kitosan juga dapat dimodifikasi melalui aktivasi karbon, seperti halnya dalam penggunaan tanah liat dan arang sebagai adsorben, tetapi biaya yang digunakan untuk aktivasi karbon tidak sebanding dengan daya adsorbsinya yang lemah (Say et al., 2008).
Kitosan umumnya larut dalam suasana asam dan kelarutannya berkurang seiring dengan kenaikan $\mathrm{pH}$ (Koide, 1998). Akibatnya, penggunaan kitosan dalam bahan pangan akan mempengaruhi cita rasa produk pangan tersebut. Modifikasi kitosan dapat membuat kelarutannya meningkat dalam $\mathrm{pH}$ netral sehingga dapat digunakan secara luas dalam bahan pangan. Chung et al. (2004) membuat maltosa-kitosan yang larut air melalui reaksi Maillard. Penambahan gugus O-suksinil ke dalam kitosan melalui proteksi gugus amino juga dapat meningkatkan kelarutan kitosan dalam air (Zhang et al., 2003). Karboksimetil kitosan merupakan salah satu turunan kitosan yang larut dalam air dan cukup banyak disintesis. Karboksimetil kitosan dibuat melalui penambahan monokloroasetat terhadap kitosan dalam kondisi basa (Bader \& Birkholz, 1997). Menurut Dwiyitno et al. (2004), suhu yang digunakan pada reaksi esterifikasi mempengaruhi kelarutan dan karakteristik karboksimetil kitosan. Semakin tinggi suhu yang digunakan maka semakin tinggi pula rendemen karboksimetil kitosan yang didapatkan.

\section{Selulosa}

Bahan-bahan alam yang mengandung lignoselulosa seperti batang pisang, sabut kelapa, serbuk gergaji, dan jerami mempunyai kemampuan

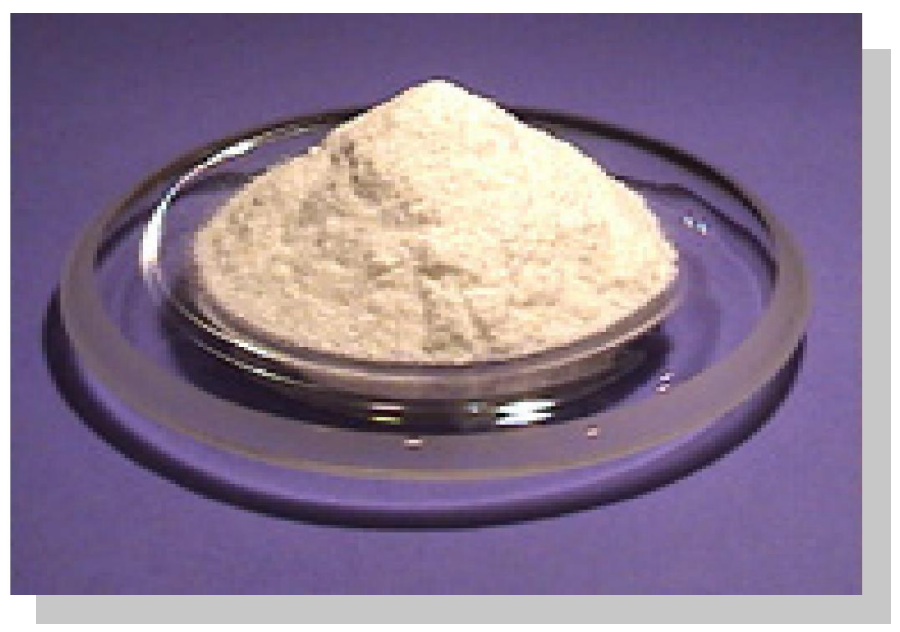

Gambar 2. Bubuk karboksimetil kitosan (Anon., 2009b). 


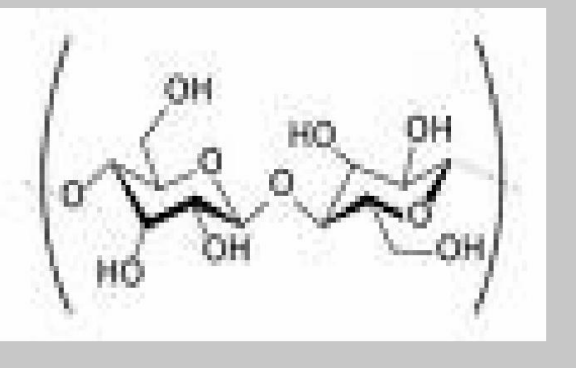

Gambar 3. Struktur selulosa (Anon., 2009c).

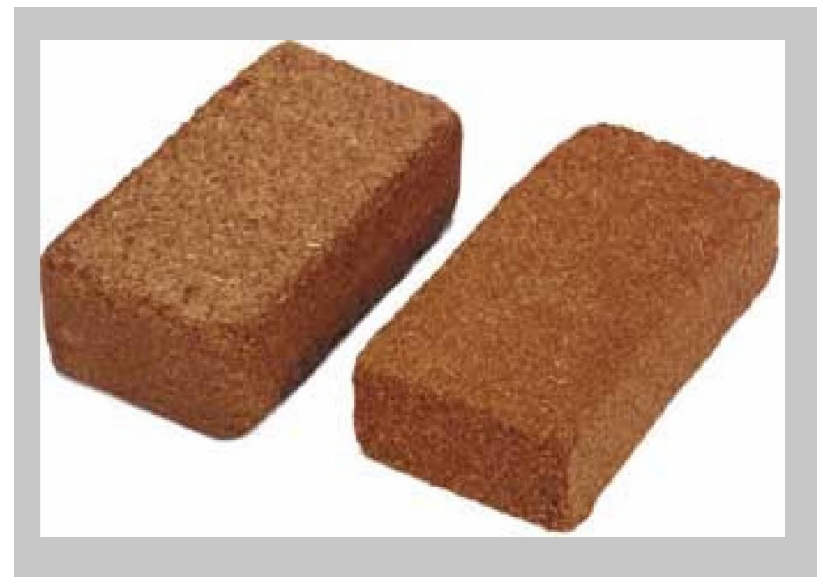

Gambar 4. Selulosa dari bahan alami sabut kelapa (coir pith) yang sudah siap digunakan sebagai adsorben (Anon., 2009d).

adsorbsi yang cukup baik. Kemampuan adsorbsi bahan-bahan tersebut dipengaruhi oleh zat-zat yang terikat dengan selulosa seperti lignin, tanin, dan pektin yang mengandung gugus polifenol, hidroksil alifatik, dan karboksil (Anirudhan et al., 2008). Kelemahannya adalah tidak bisa bertahan lama dalam kolom serta mengeluarkan berbagai zat organik selama proses adsorbsi. Modifikasi yang dilakukan untuk meningkatkan kemampuan selulosa dalam mengadsorbsi logam berat secara garis besar dapat dilakukan dengan dua cara yaitu cara langsung dan cara grafting, yaitu mengganti monomer tertentu dengan selulosa dengan membuat ikatan cabang.

Modifikasi Selulosa

\section{a. Modifikasi selulosa secara langsung}

Modifikasi selulosa secara langsung dilakukan dengan 4 cara yaitu esterifikasi, eterifikasi, halogenasi, dan oksidasi (O'Connell et al., 2008). Low et al. (2004) melakukan esterifikasi dengan menggunakan panas untuk mengubah asam sitrat menjadi asam sitrat anhidrat, yang kemudian direaksikan dengan gugus hidroksil selulosa pada serbuk kayu. Reaksi alkali selulosa dengan senyawa organo halida adalah cara yang umum digunakan untuk mendapatkan eterselulosa (Navaro et al., 1996). Saliba et al. (2005) memodifikasi serbuk gergaji dengan gugus amidoksim (hidroksilamida) dengan cara mereaksikannya dengan akrilonitril melalui reaksi eterifikasi. Aoki et al. (1999) melakukan reaksi halogenasi untuk memodifikasi bubuk selulosa. Gugus pengkelasi yang digunakan adalah gugus karboksil, sistein (campuran amino dengan karboksil), hidroksil, dan amino. Selulosa yang bersifat reaktif dapat dimodifikasi melalui reaksi oksidasi. Maekawa \& Koshijima (1990), mereaksikan natrium metaperiodat sebagai gugus pengkelasi dengan dialdehid selulosa melalui reaksi oksidasi untuk mendapatkan selulosa-asam hidroksamid.

\section{b. Metode grafting}

Pembentukan kopolimerasisasi secara grafting merupakan proses pembentukan cabang kopolimer melalui ikatan kovalen antara rantai samping senyawa yang akan dicabangkan dengan rantai utama polimer (O'Connell et al., 2008). Reaksi ini bisa terjadi jika terdapat sisi aktif dari rantai polimer dalam bentuk radikal bebas atau gugus ionik (Nasef \& El Sayed, 2004). Ada tiga metode yang biasa digunakan untuk mengaktivasi atau menginisiasi polimer selulosa yaitu fotokimia, penggunaan energi tinggi dan inisiasi secara kimia (Bhattacharya \& Misra, 2004). Kubota \& Suzuki (1995) membuat adsorben dari 
bubur kayu dengan teknik fotokimia. Gugus pengkelasi yang digunakan adalah akrilonitril, amidoksin, dan amino. Abdel-Aal et al. (2006) menyiapkan adsorben dari bubur kayu menggunakan teknik inisiasi radiasi energi tinggi. Gugus pengkelasi yang digunakan adalah gugus karboksil dari asam akrilik. Selulosa yang berasal dari serbuk gergaji, batang pisang, dan bubuk selulosa dimodifikasi menggunakan teknik inisiasi kimia. Gaey et al. (2000) menggunakan gugus karboksil dari asam akrilik sebagai gugus pengkelasi pada pembuatan adsorben dari serbuk gergaji, sementara Raji \& Anirudhan (1998) menggunakan gugus amino dari akrilamida untuk bahan yang sama. Guclu et al. (2003) menggunakan gugus karboksil dari akrilik untuk membuat adsorben dari bubuk selulosa komersial. Shibi \& Anirudhan (2002), menggunakan akrilamida, etilendiamin, dan sukinik anhidrat untuk membuat batang pisang menjadi adsorben yang dapat mengadsorbsi logam berat.

\section{PENGURANGAN LOGAM BERAT PADA PRODUK PERIKANAN}

Umumnya adsorben digunakan untuk mengurangi cemaran logam pada air yang berasal dari limbah industri atau limbah rumah tangga. Verma et al. (1981) melakukan penelitian in vivo pengurangan logam berat pada jaringan ikan menggunakan pengkelat buatan industri yaitu NTA (Nitrilotriacetic acid), EDTA (Ethylendiaminetetraacetic acid), DDTA (3,6-dioxa-octamethylenedinitrilotetraacetic acid), DTPA (Diethylenetriamine pentaaceitic acid), dan DDC (Sodium diethyldithiocarbamate). Bahan-bahan pengkelat tersebut dilarutkan dalam air kolam, kemudian ikan Notopterus notopterus yang telah dicemari dengan logam nikel, kromium, dan merkuri ditempatkan dalam kolam tersebut lalu dilakukan pengamatan efektifitas penyerapan setelah satu minggu. Kemampuan dari masing-masing bahan pengkelat tersebut untuk mengikat logam berat berbeda-beda pada setiap logam. Persentase adsorbsi logam berat dari masing-masing adsorben yang digunakan dalam penelitian Verma et al. (1981) ditunjukkan dalam Tabel 1. Pada Tabel 1 terlihat bahwa penggunaan DDC untuk mengadsorbsi nikel lebih baik dibanding bahan pengkelat lainnya $(48,19 \%)$. Sementara itu untuk mengadsorbsi kromium penggunaan DTPA lebih efektif $(40,83 \%)$ dan untuk mengadsorbsi merkuri penggunaan EDTA lebih efektif $(45,59 \%)$.

Beberapa penelitian pemanfaatan kitosan dalam mengadsorbsi logam berat pada produk perikanan juga sudah dilakukan. Larutan kitosan dan Iarutan karboksimetil kitosan dapat mengurangi cemaran logam pada kerang hijau (Perna viridis) (Murtini et al., 2004 dan Murtini et al., 2008). Menurut Murtini et al. (2004), faktor konsentrasi kitosan dan waktu perendaman kerang hijau dalam larutan kitosan berpengaruh nyata pada penurunan kadar merkuri dalam daging kerang. Penelitian tersebut menggunakan 3 variasi konsentrasi kitosan $(0,5,1,0$; dan $1,5 \%)$ dan 3 variasi waktu perendaman $(1,2$, dan 3 jam). Adsorbsi merkuri terbesar diperoleh pada penggunaan $1,5 \%$ kitosan dengan waktu perendaman 3 jam yaitu sebesar $94,89 \%$. Konsentrasi dan waktu perendaman yang optimum dapat diketahui jika dalam penelitian tersebut konsentrasi kitosan dan waktu perendaman ditingkatkan, sampai diperoleh nilai

Tabel 1. Adsorbsi logam berat pada lambung Notopterus notopterus menggunakan beberapa pengkelat

\begin{tabular}{lccccccc}
\hline \multirow{2}{*}{$\begin{array}{c}\text { Jenis } \\
\text { logam }\end{array}$} & $\begin{array}{c}\text { Akumulasi } \\
\text { logam awal } \\
(\mathbf{m g})\end{array}$ & \multicolumn{6}{c}{ Akumulasi logam setelah ditambah bahan pengkelat (mg) } \\
\cline { 3 - 8 } & $\begin{array}{c}\text { Kontrol } \\
(\text { air) }\end{array}$ & NTA & EDTA & DDTA & DTPA & DDC \\
\hline Nikel & 6.00 & 5.54 & 4.30 & 4.12 & 4.16 & 4.82 & 2.87 \\
& & & $(22.38)$ & $(25.63)$ & $(24.90)$ & $(12.99)$ & $(48.19)$ \\
Kromium & 24.60 & 24.00 & 20.85 & 15.94 & 19.20 & 14.20 & 19.70 \\
& & & $(13.13)$ & $(33.58)$ & $(20.00)$ & $(40.83)$ & $(17.91)$ \\
Merkuri & 7.10 & 6.69 & 5.40 & 3.64 & 4.97 & 4.94 & 5.02 \\
& & & $(19.28)$ & $(45.59)$ & $(25.71)$ & $(26.15)$ & $(24.96)$
\end{tabular}

Keterangan: angka di dalam kurung adalah persentase penyerapan (\%) dengan kontrol dianggap 0\% (Verma et al. (1981). 
optimum dari kurva perbandingan konsentrasi versus waktu.

Kitosan umumnya larut dalam asam sehingga penggunaannya dalam produk pangan dapat mengganggu cita rasa dari produk tersebut. Kitosan dapat dimodifikasi menjadi KMK (karboksimetil kitosan) yang larut dalam air. Kemampuan KMK dalam mengadsorbsi merkuri pada kerang hijau telah dilaporkan oleh Murtini et al. (2008). Variasi konsentrasi KMK sebanyak 0,$5 ; 1$; dan $1,5 \%$ dan waktu perendaman 1, 2, dan 3 jam tidak berbeda nyata dalam mengadsorbsi merkuri. Menurut Murtini et al. (2008), kemampuan KMK mengadsorbsi merkuri sekitar 20-30\% lebih tinggi dibanding air. Penelitian pemanfaatan selulosa sebagai adsorben yang langsung digunakan pada produk perikanan sampai saat ini belum ada. Pemanfaatan selulosa kedepannya dapat dijadikan alternatif sebagai adsorben untuk produk perikanan, mengingat sumber selulosa sangat berlimpah terutama yang berasal dari limbah pengolahan rumput laut.

\section{PENUTUP}

Metode adsorbsi pada pengurangan cemaran logam berat cukup banyak dimanfaatkan karena aplikasinya sangat luas untuk berbagai jenis logam berat. Keberhasilan dari metode adsorbsi sangat dipengaruhi oleh pemilihan adsorben yang tepat. Teknik modifikasi yang dilakukan pada adsorben juga akan mempengaruhi kemampuannya untuk menyerap logam berat. Kitosan larut asam dapat digunakan langsung pada perairan yang tercemar logam berat. Pemanfaatan kitosan sebagai adsorben dalam mengurangi cemaran logam berat pada produk perikanan harus melalui modifikasi terlebih dahulu menjadi kitosan yang larut dalam air, agar pemanfaatannya lebih luas dan tidak mengubah cita rasa dari produk tersebut. Adsorben yang berasal dari selulosa dapat dimodifikasi dengan cara langsung yaitu melalui reaksi esterifikasi, eterifikasi, halogenasi, dan oksidasi atau bisa juga dengan menggunakan metode grafting. Limbah pengolahan rumput laut merupakan sumber selulosa yang cukup berlimpah di Indonesia. Diperlukan penelitian lebih Ianjut mengenai teknik modifikasi limbah pengolahan rumput laut sehingga layak digunakan sebagai adsorben logam berat pada produk perikanan.

\section{DAFTAR PUSTAKA}

Anonim. 1990. Peraturan Pemerintah RI No. 20 Tahun 1990 Tanggal 5 Juni 1990 Tentang Pengendalian Pencemaran Air. http://www.penataanruang.net/taru/ $n s p m / P P_{-} N o 20-1990.30$ pp. Diakses pada tanggal 24 februari 2009.
Anonim. 2009a. Struktur kitosan. biotech.co.id/ content_product.html. Diakses pada tanggal 10 Januari 2009.

Anonim. 2009b. Gambar karboksimetil kitosan. www.sheng-yang.com/en/pro04.asp. Diakses pada tanggal 10 Januari 2009.

Anonim. 2009c. Struktur selulosa. ms.wikipedia.org/wiki/ Selulosa. Diakses pada tanggal 10 Januari 2009.

Anonim. 2009d. coir pith. www.cocopalm.in/html/ geotextiles.htm. Diakses pada tanggal 10 Januari 2009.

Abdel-Aal, S.E., Gad, Y., and Dessouki, A.M. 2006. The use of wood pulp and radiation modified starch in wastewater treatment. J Applied Polymer Science. 99: 2460-2469.

Aderhold, D., Williams, C.J., and Adyvean, R.G.J. 1996. The removal of heavy metals ions by seaweeds and their derivatives. Bioresource Technology. 58 (1): p.1-6.

Anirudhan, T.S., Divya, L., and Ramachandran, M. 2008. Mercury (ii) removal from aqueous solutions and wastewaters using a novel cation exchanger derived from coconut coir pith and its recovery. $J$ of Hazardous Materials. 157: 620-627.

Aoki, N., Fukushima, K., Kurakata, H., Sakamoto, M., and Furuhata, K.1999. 6-Deoxy-6-mercaptocellulose and Its S-substituted derivatives as sorbents for metal ions. Reactive and Functional Polymers. 42 (3): 223233.

Baba, Y., Matsumura, N., Shiomori, K., and Kawano, Y. 1998. Selective adsorption of mercury (ii) on chitosan derivatives from hydrochloric acid. Analytical Science. 14: 680-690.

Bader, H.J. and Birkholz, E. 1997. Teaching chitin chemistry. In Muzzareli and Peter, M.G. (eds.). Chitin Handbook. European Chitin Society. p. 507-519.

Bhattacharya, A. and Misra, B.N. 2004. Grafting: A versatile means to modify polymers: techniques, factors and applications. Progress in Polymer Science. 29 (8): 767-814.

Cestari, A.R., Vieira, E.F., Pinto, A.A., and Lopes, E.C. 2005. Multistep adsorption of anionic dyes on silica/ chitosan hybrid. 1. Comparative kinetic data from liquid and solid phase models. J. Colloid Interface Science. 292: 363-372.

Chung, Y.C., Kuo, C.L., and Chen, C.C. 2004. Preparation and important functional properties of water soluble chitosan produced through maillard reaction. Bio Resource Technology. 96: 1473-482.

Copello, G.J., Teves, S., Degrossi, J., D'Aquino, M., Desimone, M.F., and Diaz, L.E. 2006. Antimicrobial activity on glass material subject to desinfectant xerogel coating. J. Ind. Microbiol. Biotechnol. 33: 343348.

Crini, G. 2005. Recent developments in polysaccharides based materials used as adsorbents in wastewater treatment. Progress in Polymer Science 30 (1): 3870.

Dwiyitno, Basmal, J., dan Mulyasari. 2004. Pengaruh suhu esterifikasi terhadap karakteristik karboksimetil 
kitosan (CMCts). J. Penel. Perik. Indonesia 10 (3): 67-73.

Gaey, M., Marchetti, V., Clement, A., Loubinoux, B., and Gerardin, P. 2000. Recovey of heavy metal ions through decontamination of synthetic solutions and industrial effluents using modified barks, Journal of Geochemical Exploration 62 (1-3): 241-286.

Guclu, G., Gurdag, G., and Ozgumus, S. 2003. Competitive removal of heavy metal ions by cellulose graft copolymers. Journal of Applied Polymer Science. 90: 2034-2039.

IARC, 1990. Monograph on The Evaluation of Carcinogenic Risk to Humans. 49. Chromium, Nickel and Welding. International Agency for Research on Cancer, Lyon.

Koide, S.S. 1998. Chitin-Chitosan: properties, benefits and risks. Nutrition Resources. 18 (6): 1091-1101.

Kongsricharoern, N., and Polprasert, C.1996. Chromium Removal by a bipolar electrochemical precipitation process. Water Science and Technology 34 (9):109116.

Kubota, H., and Suzuki, S. 1995. Comparative examinations of reactivity of grafted celluloses prepared by ultra violet and ceric salt initiated graftings. European Polymer J. 31 (8): 701-704.

Kurniawan, T.A., Chan, G.Y.S., Lo, W.H., and Babel, S. 2006. Physicochemical treatment techniques for wastewater laden with heavy metals. Chemical Engineering J. 118 (1-2): 83-98.

Li, F., Du, P., Chen, W., and Zhang, S. 2007. Preparation of silica supported porous sorbent for heavy metals ion removal in wastewater treatment by organic-inorganic hybridization combined with sucrose and polyethylene glycol imprinting. Anal. Chem. Acta. 585: 211-218.

Low, K.S., Lee, C.K., and Mak, S.M. 2004. Sorption of Copper and Lead by Citric Acid Modified from Wood. Wood Science and Technology. 38: 629-640.

Madaeni, S.S. and Mansourpanah, Y. 2003. COD Removal from Concentrated Wastewater Using Membranes. Filtration and Separation 40 (6): 40-46.

Maekawa, E. and Koshijima, T. 1990. Preparation and characterisation of hydroxamic acid derivatives and its metal complexes derived from cellulose. Journal of Applied Polymer Science. 40: 1601-1613.

Mulyono, D. 2000. Teluk Jakarta dan Kualitas Hasil Perikanan. Lingkungan dan Pembangunan. 20 (2): 117-123.

Murtini, J.T., Januar, H.I., dan Sugiyono. 2004. Upaya pengurangan cemaran logam berat pada daging kerang hijau (Perna viridis) dengan larutan kitosan. J. Penel. Perik. Indonesia. 10 (3): 7-10

Murtini, J.T., Kurniawan, A.D., dan Dewi, E. K. 2008. Pengaruh waktu peremdaman dan konsentrasi karboksimetil kitosan untuk menurunkan kandungan logam berat $\mathrm{Hg}$, Cd, dan $\mathrm{Pb}$ pada kerang hijau (Perna viridis Linn.). J. Pascapanen dan Bioteknologi Kelautan dan Perikanan. 3 (1): 37-44.
Nasef, M.M. and El-Sayed, A.H. 2004. Preparation and applications of ion exchange membranes by radiation-induced graft copolymerisation of polar monomers onto non-polar films. Progress in Polymer Science. 29: 499-561.

Navarro, R.R., Sumi, K., Fujii, N., and Matsumura, M. 1996. Mercury Removal from Wastewater using Porous Cellulose Carrier Modified with Polyethyleneimine. Water Research. 30 (10): 2488-2494.

O'Connell, D.W., Birkinshaw, C., and O'dwyer, T.F. 2008. Heavy metal adsorbents prepared from the modification of cellulose: a review. Bioresource Technology. 99: 6709-6724.

Pagliuca, A. and Mufti, G.J.1990. Lead poisioning: an age old problem. British Medical Journal. 300: 830.

Qin, J.J., Wai, M.N., Oo, M.H., and Wong, F.S. 2002. A feasibility study on treatment and recycling of wastewater from metal plating. Journal of Membran Science. 208 (1-2): 213-221.

Raji, C. and Anirudhan, T.S.1998. Batch Cr(IV) removal by polyacrylamide grafted sawdust: kinetics and thermodynamics. Water Research 32 (12): 3772-3780.

Say, R., Birlik, E., Erdemgil, Z., Denizli, A., and ErsÖz, A. 2008. Removal of mercury species with dithiocarbamated-anchored polymer/ organosmectite composite. J. Hazardous Materials 150: 560564.

Saliba, R., Gauthier, H., and Gauthier, R. 2005. Adsorption of heavy metal ions on virgin and chemically modified lignocellulosic materials. Adsorption Science and Technology. 23 (4): 313-322.

Shibi, I.G. and Anirudhan, T.S. 2002. Synthesis, characterization and application as a mercury (II) sorbent of banana stalk polyacrilamide grafted copolymer bearing carboxyl groups. Industrial Engineering and Chemical Research. 41: 5341-5352.

Shukla, A., Zhang, Y.H., Dubey, P., Margrave, J.L., and Shukla, S.S. 2002. The role of sawdustin the removal of unwanted materials from water. Journal of Hazardous Materials. 95 (1-2): 137-152.

Theophanides, T. and Anastassopoulou, J. 2002. Copper and Carcinogenesis, Critical Reviews. Oncology/ Haematology. 42 (I): 57-64.

Verma, S.R., Jain, M., and Dalela, R.C. 1981. In vivo removal of a few heavy metals in certain tissues of the fish Notopterus notopterus. Environmental Research. 26: 328-334.

Wang, Y.H., Lin, S.H., and Juang, R.S. 2003. Removal of Heavy Metal lons from Aqueous Solutions Using Various Low Cost Adsorbents. Journal of Hazardous Materials. 102 (2-3): 291-302.

Weiss, B. and Landrigan, P.J. 2000. The Developing Brain and The Environment: an Introduction. Environmental Health Perspectives. 108: 373-374.

Zhang, C., Ping, Q., Zhang, H., and Shen, J. 2003. Synthesis and Characterization of Water Soluble OSuccinyl Chitosan. European Polymer Journal. 39: 1629-1634. 